\title{
INTERNAL COMBUSTION ENGINEERING: SCIENCE \& TECHNOLOGY
}




\section{INTERNAL \\ COMBUSTION \\ ENGINEERING: \\ SCIENCE \& \\ TECHNOLOGY}

Edited by

John H. Weaving

Technical Director, ERA Limited, London Road, Dunstable, UK

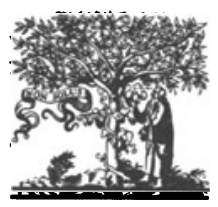

ELSEVIER APPLIED SCIENCE LONDON and NEW YORK 
ELSEVIER SCIENCE PUBLISHERS LTD

Crown House, Linton Road, Barking, Essex IG11 8JU, England

Sole Distributor in the USA and Canada

ELSEVIER SCIENCE PUBLISHING CO., INC.

655 Avenue of the Americas,

New York, NY 10010, USA

WITH 24 TABLES AND 518 ILLUSTRATIONS

(C) 1990 ELSEVIER SCIENCE PUBLISHERS LTD

(C) 1990 D. WINTERBONE, chapters 12 and 13

(C) 1990 UK ATOMIC ENERGY AUTHORITY, chapter 16, pp. 832-848

Softcover reprint of the hardcover 1st edition 1990

British Library Cataloguing in Publication Data

Internal combustion engineering.

1. Internal combustion engines

I. Weaving, John

621.43

ISBN-13: 978-94-010-6822-2

e-ISBN-13: 978-94-009-0749-2

DOI: $10.1007 / 978-94-009-0749-2$

\section{Library of Congress Cataloging-in-Publication Data \\ Internal combustion engineering: science $\&$ technology/ edited by}

John H. Weaving.

p. $\quad \mathrm{cm}$.

Includes bibliographical references.

1. Internal combustion engines-Design and construction.

I. Weaving, John $\mathbf{H}$.

TJ785.I49 1990

$621.43-\mathrm{dc} 20$

89-16991

CIP

No responsibility is assumed by the Publisher for any injury and/or damage to persons or property as a matter of products liability, negligence or otherwise, or from any use or operation of any methods, products, instructions or ideas contained in the material herein.

\section{Special regulations for readers in the USA}

This publication has been registered with the Copyright Clearance Center Inc. (CCC), Salem, Massachusetts. Information can be obtained from the CCC about conditions under which photocopies of parts of this publication may be made in the USA. All other copyright questions, including photocopying outside of the USA, should be referred to the publisher.

All rights reserved. No parts of this publication may be reproduced, stored in a retrieval system, or transmitted in any form or by any means, electronic, mechanical, photocopy-

ing, recording, or otherwise, without the prior written permission of the publisher. 


\section{Foreword}

\section{Sir Diarmuid Downs, CBE, FEng, FRS}

Engineering is about designing and making marketable artefacts. The element of design is what principally distinguishes engineering from science. The engineer is a creator. He brings together knowledge and experience from a variety of sources to serve his ends, producing goods of value to the individual and to the community. An important source of information on which the engineer draws is the work of the scientist or the scientifically minded engineer. The pure scientist is concerned with knowledge for its own sake and receives his greatest satisfaction if his experimental observations fit into an aesthetically satisfying theory. The applied scientist or engineer is also concerned with theory, but as a means to an end. He tries to devise a theory which will encompass the known experimental facts, both because an all embracing theory somehow serves as an extra validation of the facts and because the theory provides us with new leads to further fruitful experimental investigation.

I have laboured these perhaps rather obvious points because they are well exemplified in this present book. The first internal combustion engines, produced just over one hundred years ago, were very simple, the design being based on very limited experimental information. The current engines are extremely complex and, while the basic design of cylinder, piston, connecting rod and crankshaft has changed but little, the overall performance in respect of specific power, fuel economy, pollution, noise and cost has been absolutely transformed. Incentives to improvement in all these areas have been provided by market forces and latterly by regulatory pressures from Government. The information on which these performance improvements have been based has 
been provided by the kind of detailed experimental and theoretical studies described in the various chapters of this book. To provide the necessary depth of study the subject is commonly divided, as this book has been divided, into a number of specialities, and engineers have frequently devoted their whole professional careers to the detailed investigation of such subjects as combustion, noise, pollution and the dynamic behaviour of engines. By such means is progress made. But, at the end of the process, the manufacturer has to sell and the customer wishes to buy, not just a high specific output device or a low fuel consuming device, let alone a low polluting or quiet device, but an engine which gives a performance in all these respects which will satisfy the marketplace. At the end of the process we need an engineer-a designer-who will put together the complete package, making use of the information provided by his specialist colleagues.

This book is addressed to specialists, but the chapters are also designed so that one specialist can understand the work of another specialist, and relate it to his own work and to the complete engine they both aim to produce. All are written by experts, most known to me personally. Between them they provide a guide to the present state of our knowledge of the various important aspects of the internal combustion engine design and performance. One difference which it is interesting to observe, as compared with a similar book which might have been compiled some 20 years ago, is the greater use of mathematical theory which has been made possible by the availability of powerful computers. A general trend in engineering is to calculate more, for our designs to become more quantitative, with less being left to inspired guesswork, or merely based on past experience. Additionally, the creation of mathematical models, trust in which will increase as they are more fully validated by experiment, not only enables more of the engine design to be calculated quantitatively, but also enables variables to be explored within the mathematical model rather than on the test bench, thus reducing the time and cost required to produce a new engine. In the ultimate, it may be possible to look forward to the time when experimental work will be a thing of the past: all will be subject to exact calculation. This, however, is far into the future, and this book wisely gives a balanced picture of experimental work and of calculation, mutually dependent and interrelated. I have no doubt that the picture it presents and the information it contains will be of great value to all engineers and scientists working in the internal combustion engine field for many years to come. 


\section{Preface}

After so many years of development of the internal combustion (IC) engine since the days of Otto's first four-stroke engine (1876) it might have been thought that the IC engine would have been perfected. The contrary is the case, as every decade seems to throw up new challenges. The most recent challenge has been the bogey of air pollution, which started from the intolerable conditions often experienced in Los Angeles, where the climatology, combined with vast numbers of vehicles, produces the worst conditions of smog. Attention being called to this situation invited the monitoring of pollution worldwide and few cities were found to be free from pollutants. The results of these findings were severe regulations restricting the emission of carbon monoxide, oxides of nitrogen, hydrocarbons and lead. Are these regulations too severe or not severe enough?

What is the designer of a new vehicle to do to meet this challenge? Here a time factor intervenes: What can he do to meet legislation that is already promulgated or just round the corner and secondly, given time, can he design a clean economic and socially acceptable engine? It is hoped that this book will help on both counts.

For the immediate future the designer still has several alternatives. First he may take the easy way out, to accept that IC engines are polluters and decide to clean the exhaust gases with a catalyst, but there are disadvantages. Secondly he may say, 'Is a diesel engine to be preferred?' The answer is in the affirmative for commercial vehicles, and many think the same for private cars. Again, 'Can the highcompression lean-burn engine meet the challenge?' Looking to the future, 'Has the two-stroke engine advantages?' and 'What about the stratified charge type of engine?' 
It will be seen that the designer has many difficulties in reaching a decision. It would be nice to say we will lay out the required specifications, build each of these types of engines and choose the best. Unfortunately it is not as easy as this because the conventional petrol and diesel engines have undergone decades of development, while others have been largely neglected. A more fundamental approach is necessary, and it is the object of this book to examine in depth the position of each type and its potential to meet the requirements of pollution, economy and power.

The major challenge for the passenger vehicle as indicated above is between the diesel engine and the spark-ignition engine.

The situation at present, as is well known, is that the diesel engine has proved itself for the commercial vehicle due to its reliability, economy and comparatively low pollution, but although it has made inroads into the passenger car field it is still only the choice of a minority. The reasons for this are apparent. The diesel, as a slower, heavier, noisier and more costly power unit has its major appeal to those who do high mileages, because of its economy; this includes most taxis. However, careful refinements and noise insulation have made it acceptable to a wider market. With the use of a turbo-blower the weight disadvantages may be ameliorated.

The reasons for the improved fuel consumption of the diesel engine compared with the spark-ignition (SI) engine are well known; namely, the higher compression ratio and the ability-in fact, desirability-to run unthrottled. Designers and research workers are endeavouring to reduce this gap by designing lean-burn running SI engines.

Two approaches present themselves, the stratified-charge engine and the so-called high-compression lean-burn (HCLB) engine. Both these engines can potentially reduce the gap but both need further research; however, the potential is good because the reward should be a lighter engine with lower pollutants and, one hopes, a less expensive solution than the diesel.

The success of the HCLB engine is related to the octane number of the fuel available for, as most researchers will be aware, the octane number reduces the propensity of the fuel to knock or detonate, and this limits the compression ratio achievable. The higher the number the greater the resistance to knock; there are two ratings which are determined in a standardized variable-compression single cylinder CFR (Co-operative Fuel Research) engine ${ }^{1}$-the research method 
$(R O N)$, the value quoted at the pump (present 1989 four star fuel), is a minimum of 97 . The second method is the motor method (MON), which is rated on the same CFR engine except that tests are conducted with a high inlet temperature and high speed; this rating gives some guidance to 'high speed knock'. The $M O N$ is usually some 10 numbers lower than the RON. The difference $(R O N-M O N)$ is called the sensitivity. Neither of these tests correlate accurately with the performance of a multi-cylinder engine on the road. An approximate road octane number may be taken as $(R O N+M O N) / 2$.

Tetra-ethyl lead and tetra-methyl lead are the best known antiknock additives; they are being largely reduced or eliminated as they are air pollutants and also poison catalysts.

For the reasons outlined above, it will be seen that the internal combustion engine is still an exciting subject due to the need for personal door-to-door transport. Cars are made in the millions and success or failure is multiplied by a large factor.

The various chapters of this book address all these areas. Internationally well known and competent experts in each field have been chosen to give the clearest pictures of a most complex science.

As will be immediately apparent, this book is not another textbook on internal combustion engines per se; several such exist. ${ }^{2-4}$ It is intended to put before the reader the position of the most advanced research and technology in the field of IC engines so that the reader, if an industrial designer or researcher, will himself be able to incorporate some of this work to improve his product or advance his research. It will give him the status of the work being performed in the universities and other research establishments.

For the academic graduate, if just starting on his studies for a higher degree, the book will give him the up-to-date state of the art. The undergraduate wishing to examine an area in depth for a project will find much that is useful.

The lecturer will find that each subject, treated by some of the leading experts in the field, will give a basis for lectures and tools and methodology for future research.

Finally, it is with much trepidation that the editor outlines the research and development requirements that will enable a detailed specification for a clean engine for the 21 st century. Clearly, as is normal practice, the performance requirements of the vehicle are specified and this decides the power of the engine. Let us assume that 
it will be a spark-ignition (SI) piston engine. The questions that then have to be answered are:

(1) What size of engine and speed limitations are appropriate?

(2) Will it be blown or normally aspirated?

(3) What combustion chamber and valve layout is to be preferred?

(4) What compression ratio is optimum for the fuel available?

(5) How will it meet the pollution legislation?

To answer these questions a very detailed knowledge of the combustion process is required, and it is considered that in order to obtain the largest amount of information in the shortest time that computation and experiment need to go hand in hand.

If the engine concept is a new one where fundamental knowledge is lacking, an initial computation by mathematical model of the gas flow and fuel distribution will be most helpful, both in saving time in comparison with trial and error experiments and in giving a target for an achievement and a final specification. This will not eliminate experiments, as assumptions still have to be made of the physical and chemical processes, which are inordinately complex, but nevertheless it will give a clear concept of what is happening so that instruments may be positioned to give the maximum information. This information in turn can be used to refine the model. Again, computation gives an orderly discipline to a full research or development investigation, throwing up questions that need to be answered. This combination of mathematical modelling has been found to be very useful in diesel engine research and design, so the tracing of the air path and fuel spray is vital to a good engine. It has proved equally valuable in the SI field and with stratified charge engines.

The editor wishes to acknowledge and sincerely thank all the contributors to this book. The personal effort and time spent, both in writing the chapters and in the research that lies behind them, is gratefully appreciated. A not-inconsiderable proportion of this research work has been provided by grants from the Science and Engineering Research Council (SERC), under a Specially Promoted Programme on Research in Combustion Engines.

\section{REFERENCES}

1. American Society for Testing and Materials, ASTM-D2699 and ASTMD2700. ASTM, Philadelphia, USA. 
2. Benson, R. S. \& Whitehouse, N. D., Internal Combustion Engines. Oxford, Pergamon Press, 1979.

3. Heywood, J. B. Internal Combustion Engine Fundamentals. McGraw-Hill, 1988.

4. Lilly, L. C. R. (ed.)., Diesel Engine Reference Book. Butterworth, 1984.

John H. Weaving 


\section{Contents}

Foreword ................... v

Preface .................. vii

List of Contributors . . . . . . . . . . . . . . . . xv

1 Combustion in Spark-ignition Engines . . . . . . . . . 1 M. T. Overington

2 Applied Research into Combustion in Small Diesel

Engines . . . . . . . . . . . . . 33

H. K. Oetting

3 The Two-Stroke Engine: Crankcase Compression Type . 65 G. P. Blair

4 The Two-Stroke Engine: The Blowdown and Uniflow Scavenge Process . . . . . . . . . . . 103 F. J. Wallace

5 Stratified Charge Engines . . . . . . . . . . . . . 137 J. H. Weaving

6 Mixture Preparation for Spark-ignition Engines . . . . . 173 C. J. E. Nightingale 
7 Diesel Engine Fuel Injection Processes and Spray Diagnostic Methods
A. A. Hamidi \& J. Swithenbank

8 Turbulent Flows in Reciprocating Internal Combustion Engines .

R. J. Tabaczynski

9 Combustion in Gasoline Engines . . . . . . . . . . . 287 D. Bradley

10 Combustion in the Diesel Engine . . . . . . . . . 333 S. Matsuoka

11 Computer Simulation of Fluid Flow and Combustion in Reciprocating Engines . . . . . . . . . . . 385 D. B. Spalding

12 The Theory of Wave Action Approaches Applied to Reciprocating Engines . . . . . . . . . . . . . 445 D. E. Winterbone

13 The Application of Wave Action Techniques to Reciprocating Engines . . . . . . . . . . . . . . 501 D. E. Winterbone

14 The Turbocharger . . . . . . . . . . . . . . 615 B. E. Walsham \& D. E. Winterbone

15 Atmospheric Pollution . . . . . . . . . . . . . 707 J. H. Weaving \& J-P. Pouille

16 Instrumentation for Engine Flows . . . . . . . . . . . 795

C. Arcoumanis, M. Yianneskis,

D. R. Williams, C. A. Baker \& D. A. Greenhalgh

Index ................. 857 


\section{List of Contributors}

\section{Arcoumanis}

Department of Mechanical Engineering, Imperial College of Science, Technology and Medicine, Exhibition Road, London SW7 2BX, UK

\section{A. Baker}

Harwell Laboratory, UK Atomic Energy Authority, Chemical Physics Group B551 Harwell Laboratory, Oxfordshire OX11 ORA, UK

G. P. Blair

The Queen's University of Belfast, Stranmillis Road, Belfast, Northern Ireland BT9 5AH, UK

D. Bradley

Department of Mechanical Engineering, University of Leeds, Leeds, LS2 9JT, UK

D. A. Greenhalgh

Harwell Laboratory, UK Atomic Energy Authority, Chemical Physics Group B551 Harwell Laboratory, Oxfordshire OX11 ORA, UK

\section{A. A. Hamidi}

Department of Mechanical and Process Engineering, University of Sheffield, Mappin Street, Sheffield S1 3JD, UK 


\section{S. Matsuoka}

The Science University of Tokyo, 7-6-12 Seijo Setagaya-KU, Tokyo, Japan

C. J. E. Nightingale

University College London, Torrington Place, London WC1E 7JE, UK

\section{H. K. Oetting}

Volkswagen AG, Postbox 3180, Wolfsburg 1, FRG

\section{T. Overington}

Ricardo Consultants, Ricardo Consulting Engineers Ltd, Bridge Works, Shoreham-by-Sea, West Sussex BN4 5FG, UK

\section{J-P. Pouille}

Renault, 67 Rue des Bons-Raisins, 92508 Rueil Malmaison Cedex, France

\section{B. Spalding}

CHAM Ltd, Bakery House, 40 High Street, Wimbledon, London SW19 5AU, UK

\section{J. Swithenbank}

Department of Mechanical and Process Engineering, University of Sheffield, Mappin Street, Sheffield S1 3JD, UK

\section{R. J. Tabaczynski}

Ford Motor Co., PO Box 2053, Dearborn, Michigan 48121-2053, USA

\section{F. J. Wallace}

School of Mechanical Engineering, University of Bath, Claverton Down, Bath BA2 7AY, UK

B. E. Walsham

Holset Engineering Co. Ltd, PO Box A9, Turnbridge, Huddersfield HD1 6RD, UK 


\section{J. H. Weaving}

ERA Ltd, London Road, Dunstable, Bedfordshire, LU6 3UR, UK and 150 Chessetts Wood Road, Lapworth, Solihull, B94, 6EN, UK

D. R. Williams

Harwell Laboratory, UK Atomic Energy Authority, Chemical Physics Group B551 Harwell Laboratory, Oxfordshire OX11 ORA, UK

D. E. Winterbone

UMIST, PO Box 68, Manchester Road, Manchester M60 10D, UK

M. Yianneskis

School of Engineering, King's College London, University of London, Strand, London WC2R 2LS, UK 